Supporting information

\title{
Structural and functional characterization of a unique AP endonuclease from Deinococcus radiodurans
}

Supplementary Table1. Strains and plasmids used in this study

Supplementary Table2. Primes and oligonucleotides used in this study

Supplementary Table3. Data collection, phasing and refinement statistics

Supplementary Figure1. SDS-PAGE analysis of the purified full-length type and N-terminal truncated DrXth

Supplementary Figure2. Sequence alignments among DrXth and other representative ExoIII family AP endonucleases

Supplementary Figure3. Kinetic of DrXth nuclease activity

Supplementary Figure4. Analysis of ion effects on AP endonuclease activity

Supplementary Figure5. Structural comparison among DrXth, NApe, ExoIII and APE1

Supplementary Figure6. Deletion of $d r x t h$ gene in D.radiodurans R1 strain

Supplementary Figure7. Predicted structure of Gly198 mutant DrXth

Supplementary Figure8. Phenotypes of R1 strain and mutant strain under $\mathrm{H}_{2} \mathrm{O}_{2}$ stress

Supplementary Figure9. Interaction assay between DrXth and DrPolX 
Supplementary Table1. Strains and plasmids used in this study

\begin{tabular}{|c|c|c|}
\hline Strain and plasmid & Description & $\begin{array}{l}\text { Reference and } \\
\text { source }\end{array}$ \\
\hline \multicolumn{3}{|l|}{ strains } \\
\hline \multicolumn{3}{|l|}{ Deinococcus radiodurans } \\
\hline $\mathrm{R} 1$ & ATCC 13939 & $\begin{array}{l}\text { Laboratory } \\
\text { Stock }\end{array}$ \\
\hline$\Delta x t h$ & $\mathrm{R} 1$ but $x t h:: k a n$ & This study \\
\hline$\Delta x t h / p k-x t h$ & $\Delta x t h$ but pRADK:: xth & This study \\
\hline \multicolumn{3}{|l|}{ Escherichia coli } \\
\hline DH5a & E. coli cloning strain & TransGen \\
\hline BL21(DE3) & E. coli expression strain & TransGen \\
\hline \multicolumn{3}{|l|}{ plasmids } \\
\hline pET28a & $\begin{array}{l}\text { T7 promoter, T } 7 \text { transcription start, } \\
\text { His } \bullet \text { Tag coding sequence, } \mathrm{T} 7 \cdot \text { Tag } \\
\text { coding sequence, Multiple cloning } \\
\text { sites(BamH I -Xho I), T } 7 \text { terminator, } \\
\text { lacIcoding sequence, pBR } 322 \text { origin, } \\
\text { Kanr, f1 origin, } 6 \text { His-tag coding } \\
\text { sequence }\end{array}$ & Novagen \\
\hline pET28S & $\begin{array}{l}\text { pET28 plasmid modified with a } \\
\text { Strep-tag sequence (WSHPQFEK) }\end{array}$ & $\begin{array}{l}\text { Laboratory } \\
\text { Stock }\end{array}$ \\
\hline pET28aXth & pET 28 a containing wild type $x t h$ gene & This study \\
\hline $\mathrm{pET} 28 \mathrm{aXth} \Delta 22$ & $\begin{array}{l}\text { pET28a containing wild type } \\
\text { N-terminus domain of } x \text { th gene }\end{array}$ & This study \\
\hline pET28S-Xth & pET28S containing wild type $x$ th gene & \\
\hline $\mathrm{pET} 28 \mathrm{aD} 177 \mathrm{~N}$ & $\begin{array}{l}\text { pET28a containing } x \text { th directed site } \\
\text { D155N mutation gene }\end{array}$ & This study \\
\hline pET28a & pET28a containing $x$ th directed site & This study \\
\hline $\mathrm{S} 143 \mathrm{~A} / \mathrm{N} 234 \mathrm{~A} / \mathrm{R} 235 \mathrm{~A}$ & $\begin{array}{l}\text { S121A/N212A/R213A triple mutation } \\
\text { gene }\end{array}$ & \\
\hline pET28aG198H & $\begin{array}{l}\text { pET28a containing } x \text { th directed site } \\
\text { G176H mutation gene }\end{array}$ & This study \\
\hline pET28aG198A & $\begin{array}{l}\text { pET28a containing } x \text { th directed site } \\
\text { G176A mutation gene }\end{array}$ & This study \\
\hline pET28aAPE & pET28a containing ape gene & This study \\
\hline pET28aPolA-C & $\begin{array}{l}\text { pET28a containing C-terminus domain } \\
\text { of } d r p o l A \text { gene }\end{array}$ & This study \\
\hline pET28aPolX & pET28a containing polx gene & $\begin{array}{l}\text { Laboratory } \\
\text { Stock }\end{array}$ \\
\hline PRADK & D. radiodurans shuttle vector & $\begin{array}{l}\text { Laboratory } \\
\text { Stock }\end{array}$ \\
\hline pk-xth & pRADK::xth & This study \\
\hline
\end{tabular}


Supplementary Table2. Primes and oligonucleotides used in this study

\begin{tabular}{|c|c|c|}
\hline \multicolumn{2}{|c|}{ Prime $\quad$ Sequence(5'-3') } & \\
\hline \multicolumn{3}{|c|}{ construction and complement of drxth mutant } \\
\hline xth p1 & CCCCCGAACTCGACGTG & \\
\hline xth p2(HindIII) & CCCAAGCTTCGGCGCCGACCATAGC & \\
\hline xth p3(BamHI) & CGGGATCCACCCTACCTTCTCCCCAGTACC & \\
\hline xth $\mathrm{p} 4$ & TCTGCGCTGTCCTCGGTG & \\
\hline $\mathrm{xth}$ p5 & TGCTTCTGCAAGAAGTCCGC & \\
\hline $\mathrm{xth}$ p6 & GATTCCAGCTCCACCCACCC & \\
\hline \multicolumn{3}{|c|}{ Expression of proteins } \\
\hline Xth F (NdeI) & GGAATTCCATATGTTGAGCCTCCTTGCCCCA & \\
\hline Xth R (BamHI) & CGGGATCCTCATTCAGATTCCAGCTCCACC & \\
\hline $\mathrm{Xth} \Delta 22(\mathrm{NdeI})$ & GGAATTC息ATATGATGTCTGCCCCCGCCG & \\
\hline Xth $\Delta 22$ (BamHI) & CGGGATCCTCATTCAGATTCCAGCTCCACC & \\
\hline APE1F(NdeI) & GGAATTCCATATGATGCCGAAGCGTGGGAAA & \\
\hline APE1R(BamHI) & CGGGATCCTCACAGTGCTAGGTATAGGGTGATAGG & \\
\hline PolA-C(NdeI) & GGAATTCCATATGATGGGGCTGAACGGGCCA & \\
\hline PolA-C (BamHI) & CGGGATCCTCACTTCGTGTCAAACCAGTTCG & \\
\hline \multicolumn{3}{|c|}{ Site-directed mutagenesis } \\
\hline xth $\mathrm{G} 198 \mathrm{H}(\mathrm{F})$ & GCTCGTGGGGCAGGAAATGGCTGTTTTTCTGGTTGC & \\
\hline xth G198H(R) & GCAACCAGAAAAACAGCCATTTCCTGCCCCACGAGC & \\
\hline Xth D177N(F) & GGCGATGTTGTAGTTGCCGCCGATGACGA & \\
\hline Xth D177N(R) & TCGTCATCGGCGGCAACTACAACATCGCC & \\
\hline XTH G198A(F) & CGTGGGGCAGGAAAGCGCTGTTTTTCTGG & \\
\hline XTH G198A(R) & CCAGAAAAACAGCGCTTTCCTGCCCCACG & \\
\hline Xth S143A(F) & CGCCTCGCCGGCGCTGCCGCTCG & \\
\hline Xth S143A(R) & CGAGCGGCAGCGCCGGCGAGGCG & \\
\hline $\begin{array}{l}\text { Xth } \\
\text { N234R235A(F) }\end{array}$ & GGCGTAGGCATTGGCGGCGGCGCTCCACCAGGTGTAC & \\
\hline $\begin{array}{l}\text { Xth } \\
\text { N234R235A(R) }\end{array}$ & GTACACCTGGTGGAGCGCCGCCGCCAATGCCTACGCC & \\
\hline Oligonucleotides 1 & or enzyme activity assay & \\
\hline Type of substrate & Sequence & label \\
\hline THF.T & $5^{\prime *}$ GCTATGGACTAAFAATGACTGCGTG 3' & $\mathrm{F}(\mathrm{THF})$ \\
\hline & 3'CGATCCTGATTTTTACTGACGCAC5' & $*(\mathrm{FAM})$ \\
\hline Exo40.T & ATGACAACTAAAGCAACACC3' 5'GATAGAACGACCGCCAGTG3' & $*(\mathrm{FAM})$ \\
\hline & 3'TACTGTTGATTTCGTTGTGGTCTATCTTGCTGGCGGTCAC5' & \\
\hline Exo40 ${ }^{\mathrm{P}} . \mathrm{T}$ & ATGACAACTAAAGCAACACC ${ }^{\mathrm{P}}{ }^{\prime} \quad$ 5'GATAGAACGACCGCCAGTG3' & $*(\mathrm{FAM})$ \\
\hline & 3'TACTGTTGATTTCGTTGTGGTCTATCTTGCTGGCGGTCAC5' & \\
\hline Exo40 ${ }^{\mathrm{THF}} . \mathrm{T}$ & 'ATGACAACTAAAGCAACACCF 5'GATAGAACGACCGCCAGTG3' & $\mathrm{F}(\mathrm{THF})$ \\
\hline & 3'TACTGTTGATTTCGTTGTGGTCTATCTTGCTGGCGGTCAC5' & $*(\mathrm{FAM})$ \\
\hline$\alpha \mathrm{dA}$ & $5^{\prime *}$ TGACTGCATAXGCATGTAGACGATGTGCAT3' & $\mathrm{X}(\alpha \mathrm{dA})$ \\
\hline & 3'ACTGACGTATACGTACATCTGCTACACGT5' & *(FAM) \\
\hline
\end{tabular}


Supplementary Table3. Data collection, phasing and refinement statistics

\begin{tabular}{lc}
\hline & DrXth \\
\hline Data collection & \\
\hline Space group & $P 2{ }_{1}{ }_{1} 2_{1}$ \\
Cell dimensions & \\
$\quad a, b, c(\AA)$ & 57.42 \\
& 58.86 \\
& 74.28 \\
Wavelength $(\AA)$ & 0.9792 \\
Resolution $(\AA)$ & $30.0-1.50$ \\
$R_{\text {sym }}(\%)$ & $6.6(47.3)$ \\
$I / \sigma I$ & $14.6(4.3)$ \\
Completeness $(\%)$ & 98.2 \\
& $(91.0)$ \\
Redundancy & $5.1(3.4)$ \\
\hline Refinement & \\
\hline Resolution $(\AA)$ & $30.0-1.50$ \\
No. reflections & 40705 \\
$R_{\text {work/ }} R_{\text {free }}$ & $18.6 / 20.4$ \\
No. atoms & \\
$\quad$ Protein & 1941 \\
$\quad$ Water & 243 \\
B-factors & \\
$\quad$ Protein & 19.3 \\
$\quad$ Water & 32.0 \\
R.m.s deviations & \\
Bond lengths $(\AA)$ & 0.005 \\
Bond angles $\left({ }^{\circ}\right)$ & 0.865 \\
\hline
\end{tabular}

*Highest resolution shell is shown in parenthesis. 
A

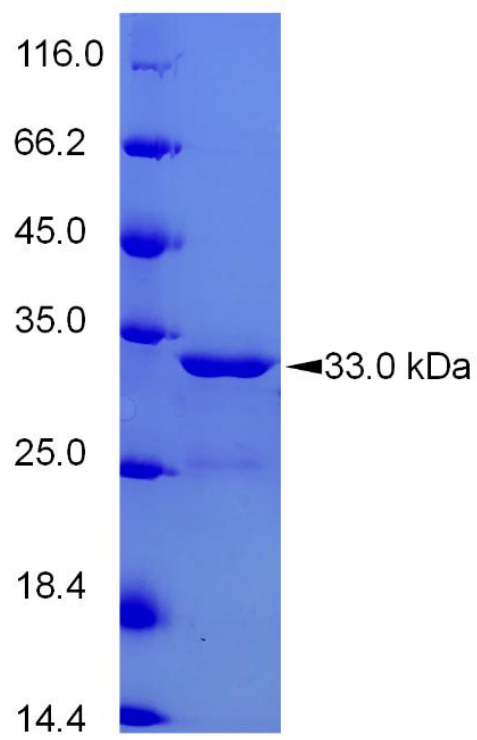

B

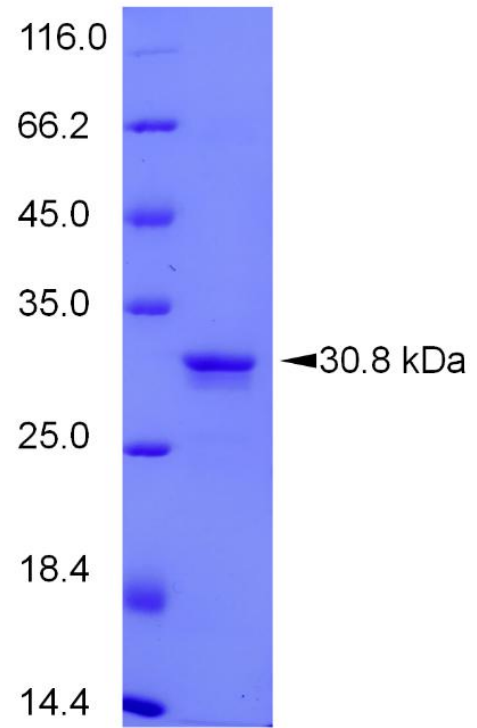

Supplementary Figure1. SDS-PAGE analysis of the purified full-length type and $\mathrm{N}$-terminal truncated DrXth. (A) Molecular weight of full-length type DrXth protein with His-tag is $33.0 \mathrm{kDa}$. (B) Molecular weight of N-terminal truncated DrXth protein (N $\Delta 22 \mathrm{DrXth})$ with His-tag is $30.8 \mathrm{kDa}$. 

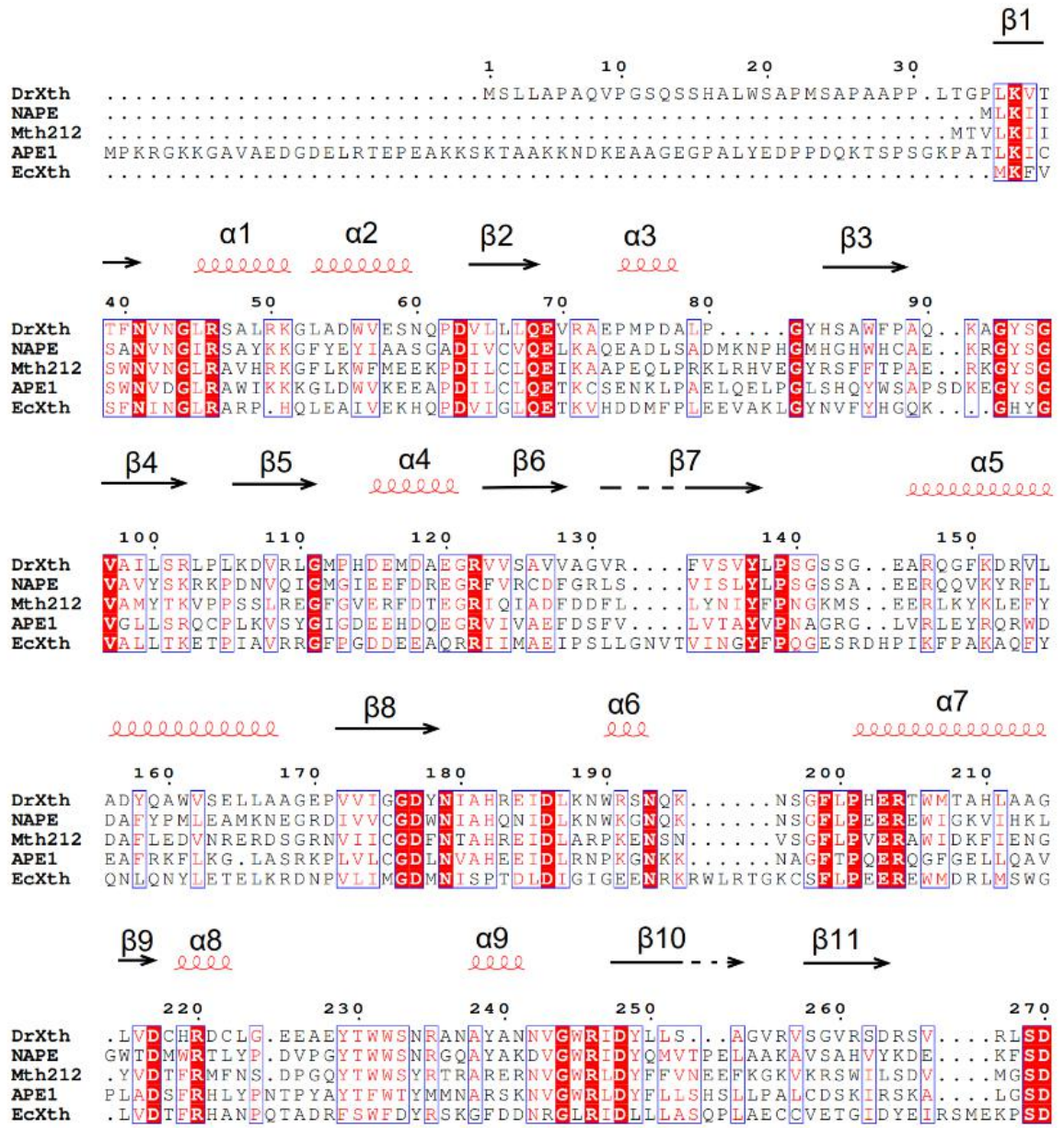

$\stackrel{\beta 12}{\longrightarrow}$

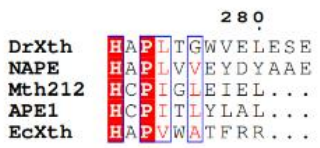

Supplementary Figure2. Sequence alignments among DrXth and other representative ExoIII family AP endonucleases. DrXth, Deinococcus radiodurans; NApe, Neisseria meningitidis; Mth212, Methanobacterium thermoautotrophicum; APE1, Homo sapiens; EcXth, Escherichia coli. 
A

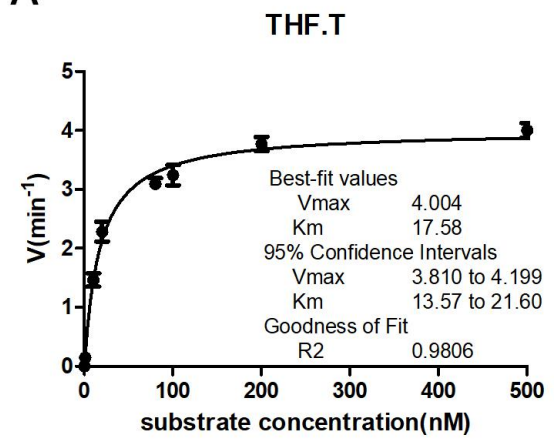

C

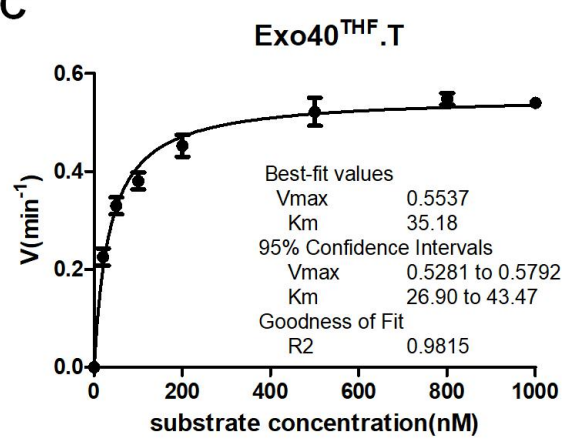

B

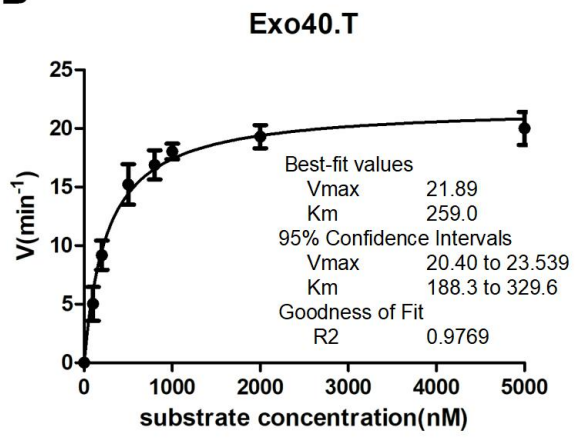

D

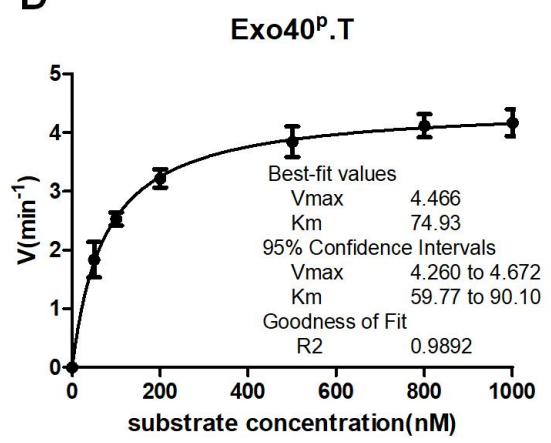

Supplementary Figure3. Kinetic of DrXth nuclease activity. (A) DrXth (1 nM) was incubated with increasing amounts of THF.T substrate $(1,10,50,80,100,200,500 \mathrm{nM})$ at $37^{\circ} \mathrm{C}$ for $3 \mathrm{~min}$. (B) DrXth $(3 \mathrm{nM})$ was incubated with increasing amounts of Exo40.T substrate $(200,500,800,1000,2000,5000 \mathrm{nM})$ at $37^{\circ} \mathrm{C}$ for $3 \mathrm{~min}$. (C) DrXth $(3 \mathrm{nM})$ was incubated with increasing amounts of Exo40THF.T substrate $(20,50,100$, $200,500,800,1000 \mathrm{nM})$ at $37^{\circ} \mathrm{C}$ for $3 \mathrm{~min}$. (D) DrXth $(3 \mathrm{nM})$ was incubated with increasing amounts of Exo40P.T substrate $(20,50,100,200,500,800,1000 \mathrm{nM})$ at $37^{\circ} \mathrm{C}$ for $3 \mathrm{~min}$. The data were fitted by the Michaelis-Menten equation in GraphPad Grism 5 in order to obtain the Kcat and Km. Best-fit values, 95\% confidence intervals and goodness of fit are shown.

A

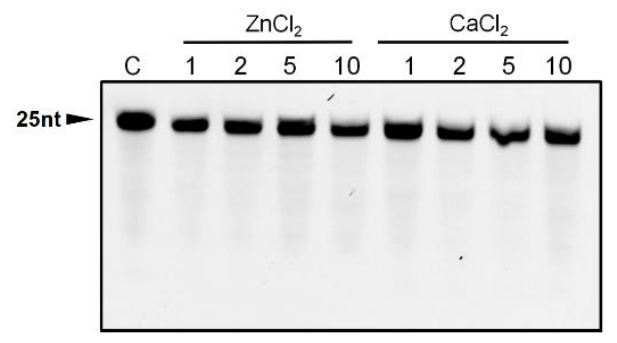

B

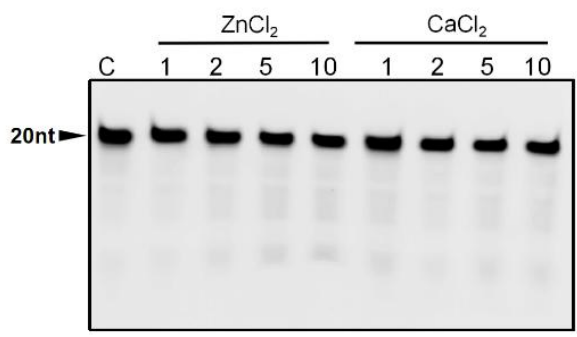

Supplementary Figure4. Analysis of ion effects on AP endonuclease activity. (A) 100 $\mathrm{nM}$ THF.T duplex was incubated with $2 \mathrm{nM}$ DrXth in the presence of $\mathrm{CaCl}_{2}$ or $\mathrm{ZnCl}_{2}$ (1, 2,5 or $10 \mathrm{mM}$ ) at $37^{\circ} \mathrm{C}$ for $5 \mathrm{~min}$. (B) $100 \mathrm{nM}$ Exo40.T 1nt gap duplex was incubated 
with $10 \mathrm{nM}$ DrXth in the presence of $\mathrm{CaCl}_{2}$ or $\mathrm{ZnCl}_{2}(1,2,5$ or $10 \mathrm{mM})$ at $37^{\circ} \mathrm{C}$ for 5 $\min$.

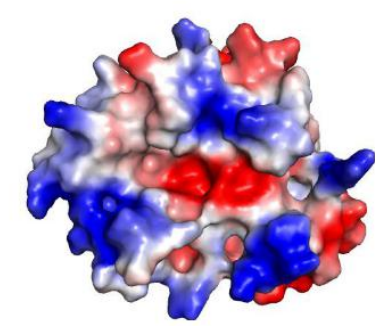

DrXth

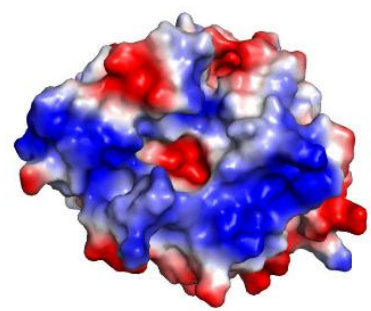

ExoIII

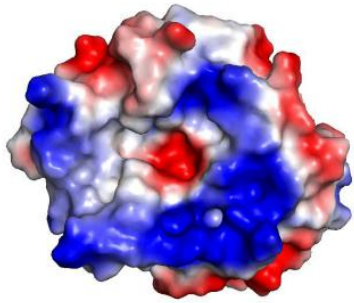

NApe

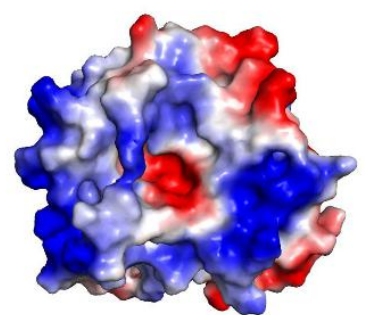

APE1

Supplementary Figure5. Structural comparison among DrXth, NApe, ExoIII and APE1. The structure shows the distribution of the electrostatic surface. Blue and red represent negative and positive charge potencial at + and $-70 \mathrm{kTe}^{-1}$ scale, respectively.

A

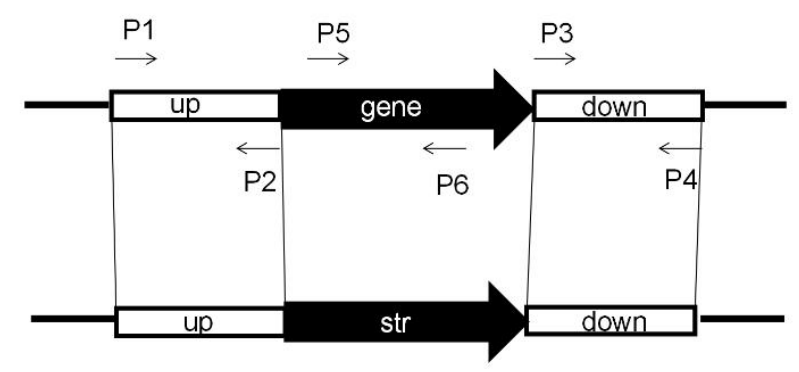

B

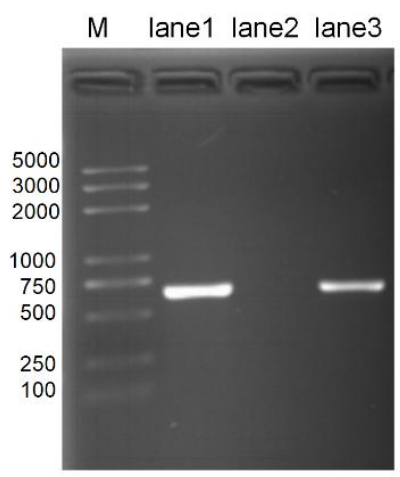

Supplementary Figure6. Deletion of $d r x t h$ gene in D.radiodurans R1 strain (A) Scheme of gene mutation by homologous recombination that replaced the target ORFs with streptomycin-resistant fragment. P1, P2, P3, P4, P5 and P6 refer to the primer pairs (Supporting information Table2). (B) PCR analysis to confirm the mutation of $d r x t h$. An interior DNA fragment ( $652 \mathrm{bp}$ ) of the targeted gene was detected by amplification using primers $\mathrm{P} 5$ and $\mathrm{P} 6$. No products corresponding to the size of the fragment was observed from mutant (lane 2) but observed in the wild type (lane 1) and compensation type (lane 3 ), suggesting that the wild type alleles were completely replaced by streptomycin-resistance fragment in the mutant. 

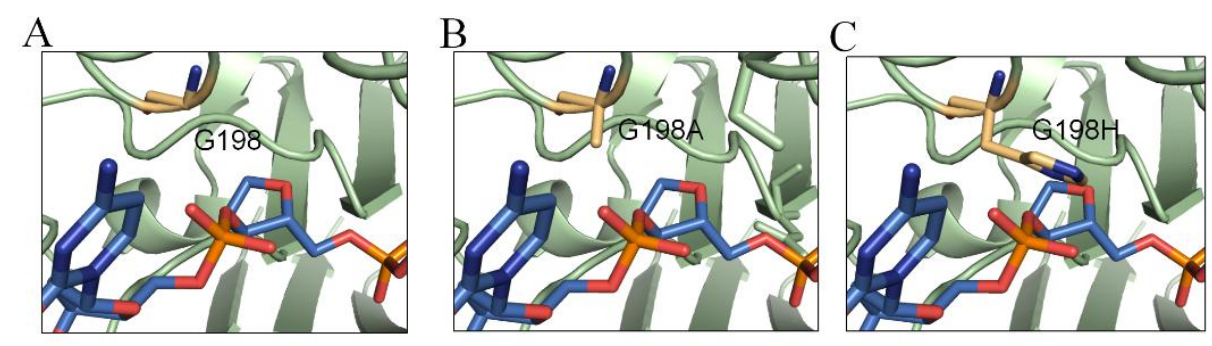

Supplementary Figure7. Predicted structure of Gly198 mutant DrXth. DNA from NApe-DNA complex were docked onto the DrXth by superposition between DrXth and NApe. (A) DrXth (B) Substitue Ala for Gly198 (C) Substitute His for Gly198.

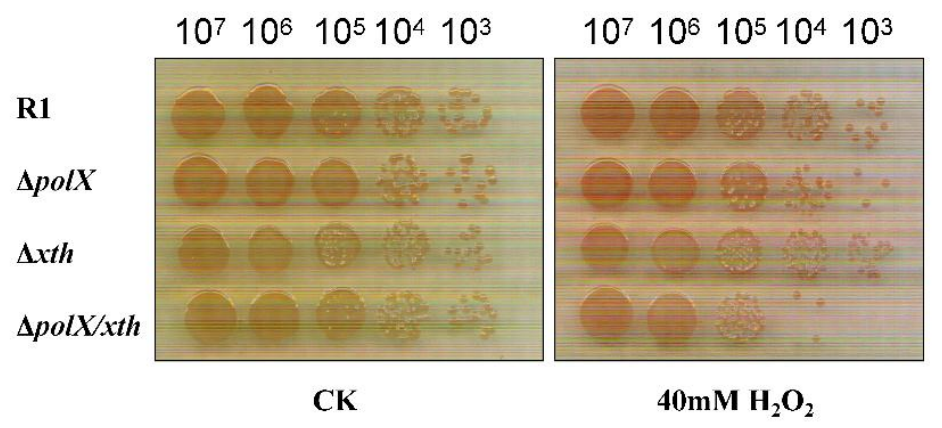

Supplementary Figure8. Phenotypes of R1 strain and mutant strain under $\mathrm{H}_{2} \mathrm{O}_{2}$ stress. Growth and $\mathrm{H}_{2} \mathrm{O}_{2}$ resistance features of wild type (R1), drpolX disruptant $(\Delta p o l X)$, drxth disruptant $(\Delta x t h), d r p o l X$-drxth double disruptant $(\Delta p o l X / x t h)$. Cells were incubated with $\mathrm{H}_{2} \mathrm{O}_{2}(40 \mathrm{mM})$ for $30 \mathrm{~min}$ and then the reaction were stopped by excess catalyase for $15 \mathrm{~min}$. After treatment, the cells were serially diluted 1:10 and spotted on TGY agar plates, and then cultivated at $30^{\circ} \mathrm{C}$ for 3 days. 


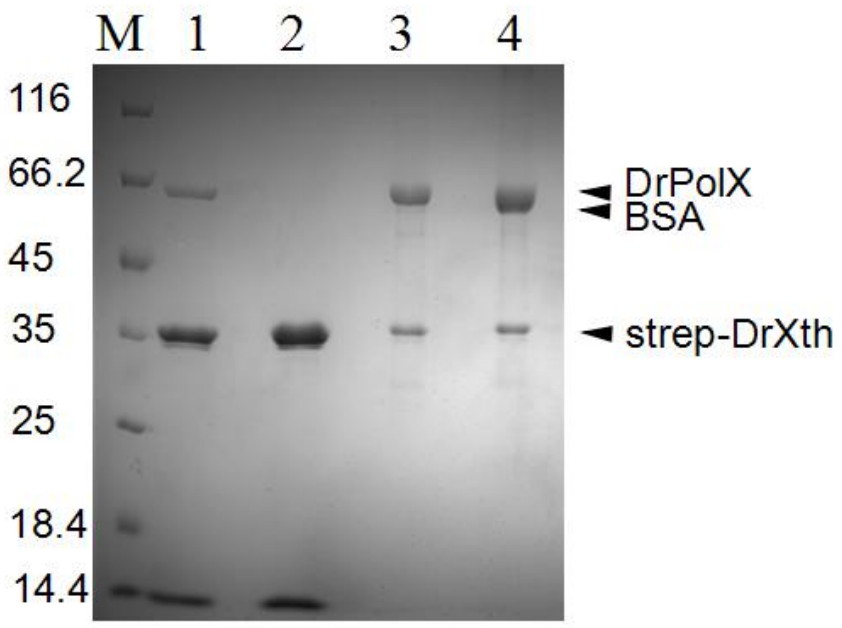

Supplementary Figure9. Interaction assay between His-Strep- DrXth and DrPolX. His-Strep-DrXth (N-terminal fused streptavidin tag) binding with strep-beads were rotating incubated with DrPolX and BSA at $4{ }^{\circ} \mathrm{C}$ for $3 \mathrm{~h}$. Lane1: His-Strep-DrXth and DrPolX were pulled-down by strep-beads. Lane2: His-Strep-DrXth and BSA (input control) were pulled by strep-beads. Lane3: His-Strep-DrXth and DrPolX. Lane4: His-Strep-DrXth and BSA (input control). 